\title{
APLIKASI SOCIAL RESPONSIBILITY: KEGIATAN BAKTI SOSIAL DALAM MASA PANDEMI COVID-19 DI KELURAHAN KUKUSAN RT 06 RW 05 KECAMATAN BEJI KOTA DEPOK JAWA BARAT 16425
}

\author{
Mutmainnah, Arif Siaha Widodo, Ahmad Dimyati, Hanum Puspa Dhiani, \\ Surti Wardani \\ Universitas Pamulang \\ Email:dosen01725@unpam.ac.id
}

\begin{abstract}
In early 2020 the world was shocked by the outbreak of a new virus called the corona virus or the novel Corona virus 2019 (nCov-19 or better known as COVID-19) allegedly originating from the Wuhan area in China in December 2019. COVID-19 is a large family of viruses that cause mild to severe illness, such as the common cold or colds and serious illnesses such as MERS, SARS and pneumonia. Everyone is at risk of being infected with COVID-19, especially children and the elderly who have low immunity. The spread of this virus is thought to have originated from animals and then infected humans. Transmission of the virus between humans can be through droplets from coughing or sneezing and touching the eyes, nose or mouth after straining objects or people who have a COVID-19 infection. The existence of the PSBB certainly reduces the space for the community, especially for workers who have to be mobile and meet many people on a daily basis. Some industries have been paralyzed by production and have even been forced to 'lay off' their employees due to difficulties running a business during the COVID-19 pandemic. In addition to the increasing number of residents who have lost their jobs, the emergence of panic buying has resulted in scarcity of some foodstuffs, even the prices of basic and health goods (such as masks, hand sanitizers) have soared. Residents who have lost their income coupled with difficulties in buying basic commodities have certainly caused their quality of life to decline. The government has tried to provide social assistance to village communities, but in fact not all have received these benefits. This has led to empathy from people who are more able to start social service movements or crowdfunding. Social service or better known as baksos is one of the activities resulting from a sense of humanity that arises for others. Whereas crowdfunding or crowdfunding (fundraising) is the process of raising a number of funds that aims to run a project or business and is generally done online. The project referred to here is the campaign or social service activity itself. Therefore, we held Community Service (PKM) with the theme "Social Responsibility Application: Social Service Activities during the COVID-19 Pandemic in Kukusan Village RT 06 RW 05 Beji District, Depok City, West Java 16425". The targets of the participants in this activity are people affected by Covid19 who need them in Beji District, Depok City. The method of implementing this PKM is in the form of distribution of basic necessities by the Unpam
\end{abstract}


Lecturer Team and the village officials. The result of this activity was that representatives of the UNPAM lecturer team conducted random distribution checks by visiting several residents' houses. This is done to ensure that basic food assistance is evenly distributed among local residents affected by Covid-19. It is hoped that residents will be more aware of various things that can spread the corona virus, residents' awareness of personal hygiene and the environment in which they live, etc.

Keywords: Society, Services, Public Service Management, Covid-19 Pandemic, Fundraising, Social Service.

\begin{abstract}
Abstrak
Awal tahun 2020 dunia dihebohkan dengan outbreak virus baru yang disebut virus corona atau novel Corona virus 2019 (nCov-19 atau lebih dikenal dengan COVID-19) diduga berasal dari daerah Wuhan di Cina pada Desember 2019. COVID-19 merupakan keluarga besar virus yang menyebabkan penyakit ringan sampai berat, seperti common cold atau pilek dan penyakit yang serius seperti MERS, SARS serta pneumonia. Setiap orang berisiko terinfeksi COVID-19, terutama anak-anak maupun lansia yang memiliki kekebalan tubuh rendah. Penyebaran virus ini diduga bersumber dari hewan kemudian menginfeksi manusia. Transmisi virus antar manusia ini dapat melalui droplet dari batuk atau bersin serta menyentuh mata, hidung atau mulut setelah menegang barang atau orang yang terkena infeksi COVID-19. Adanya PSBB tentu mengurangi ruang gerak masyarakat apalagi para pekerja yang kesehariannya harus mobile dan bertemu dengan banyak orang. Beberapa industri lumpuh produksi bahkan terpaksa 'merumahkan' karyawannya karena kesulitan menjalankan bisnis di masa pandemi COVID-19. Selain meningkatnya jumlah warga yang kehilangan pekerjaan, timbulnya panic buying menyebabkan kelangkaan beberapa bahan makanan, bahkan harga bahan-bahan pokok dan kesehatan (seperti masker, hand sanitizer) menjadi melambung tinggi. Warga yang telah kehilangan pendapatan ditambah pula kesulitan dalam membeli bahanbahan pokok tentunya menyebabkan kualitas hidup mereka menurun. Pemerintah sudah mencoba memberikan bantuan sosial kepada masyarakat desa, namun nyatanya belum semua menerima manfaat tersebut. Hal ini yang kemudian menimbulkan empati dari masyarakat yang lebih mampu untuk memulai gerakan bakti sosial atau crowdfunding. Bakti sosial atau lebih dikenal dengan baksos merupakan salah satu kegiatan hasil dari rasa kemanusiaan yang timbul untuk sesama. Sedangkan crowdfunding atau urun dana (penggalangan dana) merupakan proses mengumpulkan sejumlah dana yang bertujuan untuk menjalankan suatu proyek atau usaha dan umumnya dilakukan secara daring. Proyek yang dimaksud disini adalah kampanye atau kegiatan bakti sosial itu sendiri. Oleh karena itu kami mengadakan Pengabdian Kepada Masyarakat (PKM) dengan tema "Aplikasi Social Responsibility : Kegiatan Bakti Sosial dalam Masa Pandemi COVID-19 di Kelurahan Kukusan RT 06 RW 05 Kecamatan Beji Kota Depok Jawa Barat 16425". Sasaran peserta kegiatan ini adalah masyarakat terdampak covid-19 yang membutuhkan di Kecamatan Beji Kota Depok. Metode pelaksanaan PKM ini berupa pendistribusian sembako yang dilakukan Tim Dosen
\end{abstract}


Unpam beserta pihak kelurahan. Hasil kegiatan ini adalah Perwakilan tim dosen UNPAM melakukan pengecekan distribusi secara acak dengan mendatangi beberapa rumah warga. Hal ini dilakukan untuk memastikan bahwa bantuan sembako sudah terdistribusi merata di kalangan warga setempat terdampak covid-19. Diharapkan agar warga lebih waspada terhadap berbagai hal yang dapat menyebarkan virus corona, kesadaran warga tehadap kebersihan diri dan lingkungan tempat tinggal, dll.

Kata Kunci: Masyarakat, Pelayanan, Manajemen Pelayanan Publik, Pandemi Covid-19, Penggalangan Dana, Bakti Sosial.

\section{A. PENDAHULUAN}

Kehidupan masyarakat yang dipengaruhi oleh dunia bisnis memudahkan manusia dalam meningkatkan kualitas hidupnya. Penggunaan akan produk yang berkualitas serta lapangan kerja yang tersedia membuat taraf hidup banyak orang menjadi lebih baik dari sebelumnya. Perkembangan bisnis yang pesat selain memberikan manfaat tentu juga menimbulkan risiko baik pada lingkungan maupun masyarakat sekitarnya. Untuk meminimalisir risiko tersebut muncullah tanggung jawab sosial dari para pelaku bisnis atau yang dikenal sebagai Corporate Social Responsibility (CSR).

Tanggung jawab sosial merupakan usaha suatu bisnis untuk menyeimbangkan komitmennya terhadap kelompok dan individu dalam lingkungannya, termasuk konsumen, bisnis lain/pesaing, karyawan, dan investor (Griffin \& Ebert, 2002 dalam Isman, 2017). Dimulai dari konferensi United Nation Global Impact yang diadakan di Geneva, Swiss, pada 5 Juli 2007, peserta konferensi yang merupakan eksekutif senior korporasi dunia sepakat untuk memperbaiki praktik bisnis yang memperhatikan lingkungan hidup dan apsek sosial baik di dalam maupun di luar perusahaan. Menurut Bank Dunia, tanggung jawab sosial perusahaan terdiri dari beberapa komponen utama: perlindungan Iingkungan, jaminan kerja, hak azasi manusia, interaksi dan keteribatan perusahaan dengan masyarakat, standar usaha, pasar, pengembangan ekonomi dan badan usaha, perlindungan kesehatan, kepemimpinan dan pendidikan, bantuan bencana kemanusiaan (Ernawan, 2014). Di Indonesia sendiri tanggung jawab sosial perusahaan secara yuridis telah dinyatakan sebagaimana dalam Undang-undang No. 40 Tahun 2007, tentang Perseroan Terbatas, Bab V, Pasal 74. Dalam pasal tersebut dijelaskan tanggung jawab sosial dan lingkungan dari perusahaan atas eksistensinya dalam kegiatan bisnis. Perkembangan pelaksanaan CSR di Indonesia terlihat dari banyaknya perusahaan yang melakukan kegiatan amal (charity) maupun pemberdayaan (empowerment) (Amerta, 2018).

Keraf (1998 dalam Ernawan, 2014) menyebutkan beberapa alasan perlunya keterlibatan sosial perusahaan. Keterlibatan perusahaan tersebut antara lain:

1. Kebutuhan dan harapan masyarakat semakin berubah, masyarakat semakin kritis dan peka terhadap produk yang akan dibelinya. Sehingga perusahaan tidak bisa hanya memusatkan perhatiannya untuk mendatangkan keuntungan.

2. Terbatasnya sumber daya alam, bisnis diharapkan untuk tidak hanya mengeksploitasi sumber daya alam yang terbatas, namun harus juga memelihara dan menggunakan sumber daya secara bijak.

3. Lingkungan sosial yang lebih baik, lingkungan sosial akan mendukung keberhasilan bisnis untuk waktu yang panjang, semakin baik lingkungan sosial dengan sendirinya akan ikut memperbaiki iklim bisnis yang ada. Misalnya dengan semakin menurunnya tingkat penganguran. 
4. Perimbangan tanggung jawab dan kekuasaan, kekuasaan yang terlalu besar jika tidak diimbangi dan dikontrol dengan tanggung jawab sosial akan menyebabkan bisnis menjadi kekuatan yang merusak masyarakat.

5. Keuntungan jangka panjang, dengan tanggung jawab dan keterlibatan sosial tercipta suatu citra positif di mata masyarakat, karena terciptanya iklim sosial politik yang kondusif bagi kelangsungan bisnis perusahaan tersebut.

Kotler dan Lee (2005 dalam Ernawan, 2014) mengidentifikasi enam pilihan program bagi perusahaan untuk melakukan inisiatif dan aktivitas yang berkaitan dengan berbagai masalah sosial sekaligus sebagai wujud komitmen dari tanggung jawab sosial perusahaan. Keenam inisiatif sosial yang bisa dieksekusi oleh perusahaan adalah: Pertama, cause promotions dalam bentuk memberikan kontribusi dana atau penggalangan dana untuk meningkatkan kesadaran akan masalah-masalah sosial tertentu seperti salah satunya, bahaya narkotika. Kedua, cause-related marketing, yaitu bentuk kontribusi perusahaan dengan menyisihkan sepersekian persen dari pendapatan sebagai donasi bagi masalah sosial tertentu, untuk periode waktu tertentu atau produk tertentu. Ketiga, corporate social marketing, yaitu perusahaan membantu pengembangan maupun implementasi dari kampanye dengan fokus untuk merubah perilaku tertentu yang mempunyai pengaruh negatif, seperti misalnya kebiasaan berlalu lintas yang beradab. Keempat, corporate philantrophy adalah inisitiatif perusahaan dengan memberikan kontribusi langsung kepada suatu aktivitas amal, lebih sering dalam bentuk donasi ataupun sumbangan tunai. Kelima, community volunteering. Dalam aktivitas ini perusahaan memberikan bantuan dan mendorong karyawan, serta mitra bisnisnya untuk secara sukarela terlibat dan membantu masyarakat setempat. Keenam, socially responsible business practices yang merupakan sebuah inisiatif di mana perusahaan mengadopsi dan melakukan praktik bisnis tertentu serta investasi yang ditujukan untuk meningkatkan kualitas komunitas dan melindungi lingkungan.

Pelaksanaan CSR yang baik memiliki pengaruh positif bagi kedua belah pihak, yaitu perusahaan dan masyarakat. Bagi perusahaan dampak positifnya adalah:

1. Timbuknya citra positif perusahaan (dalam jangka panjang bisa menungkatkan laba perusahaan) sebagai perusahaan yang ramah dan peduli dengan lingkungan.

2. Meningkatkan tingkat kenyamanan bagi perusahaan karena situasi aman. Sedangkan dampak CSR bagi masyarakat adalah :

a. Mengentaskan kemiskinan, dengan memakai pekerja sekitar perusahaan mereka dapat menyumbangkan kenaikan angka angkatan kerja dan dalam menciptakan lapangan kerja, menyediakan pelatihan, menyediakan produk - produk yang di sediakan oleh orang - orang kalangan bawah maka secara langsung akan memberikan dampak kepada golongan bawah.

b. Meningkatkan standar pendidikan dengan memberikan beasiswa kepada yang benar benar yang membutuhkan dan membantu dalam pembangunan sarana prasarana pendidikan khususnya pendidikan dasar

c. Meningkatkan standar kesehatan dengan menyediakan sarana prasarana yang menunjang kesehatan terutama bagi masyarakat sekitarnya. Contohnya dengan menyediakan fasilitas air bersih, atau dengan membuka klinik kesehatan yang tidak berlaku untuk karyawannya saja, tetapi juga bagi masyarakat sekitarnya (Ernawan, 2014).

Awal tahun 2020 dunia dihebohkan dengan outbreak virus baru yang disebut virus corona atau novel Corona virus 2019 (nCov-19 atau lebih dikenal dengan COVID-19) diduga berasal dari daerah Wuhan di Cina pada Desember 2019. COVID-19 merupakan keluarga besar virus yang menyebabkan penyakit ringan sampai berat, seperti common cold atau pilek dan penyakit yang serius seperti MERS, SARS serta pneumonia. Setiap orang berisiko 
terinfeksi COVID-19, terutama anak-anak maupun lansia yang memiliki kekebalan tubuh rendah. Penyebaran virus ini diduga bersumber dari hewan kemudian menginfeksi manusia. Transmisi virus antar manusia ini dapat melalui droplet dari batuk atau bersin serta menyentuh mata, hidung atau mulut setelah menegang barang atau orang yang terkena infeksi COVID-19. Sampai saat ini, Mei 2020, para ilmuwan masih mencari vaksin untuk mengatasi penyakit tersebut. Karena belum ditemukannya vaksin serta penyebaran virus yang massive, maka beberapa cara Pemerintah mengurangi penyebaran virus tersebut adalah dengan menghimbau masyarakat untuk melakukan karantina mandiri di rumah (stay at home), pembatasan sosial (social distancing), dan memberlakukan Pembatasan Sosial Berskala Besar (PSBB) untuk beberapa daerah seperti di JABODETABEK.

Adanya PSBB tersebut tentu mengurangi ruang gerak masyarakat apalagi para pekerja yang kesehariannya harus mobile dan bertemu dengan banyak orang. Beberapa industri lumpuh produksi bahkan terpaksa 'merumahkan' karyawannya karena kesulitan menjalankan bisnis di masa pandemi COVID-19. Selain meningkatnya jumlah warga yang kehilangan pekerjaan, timbulnya panic buying menyebabkan kelangkaan beberapa bahan makanan, bahkan harga bahan-bahan pokok dan kesehatan (seperti masker, hand sanitizer) menjadi melambung tinggi. Warga yang telah kehilangan pendapatan ditambah pula kesulitan dalam membeli bahan-bahan pokok tentunya menyebabkan kualitas hidup mereka menurun. Pemerintah sudah mencoba memberikan bantuan sosial kepada masyarakat desa, namun nyatanya belum semua menerima manfaat tersebut. Hal ini yang kemudian menimbulkan empati dari masyarakat yang lebih mampu untuk memulai gerakan bakti sosial atau crowdfunding.

Bakti sosial atau lebih dikenal dengan baksos merupakan salah satu kegiatan hasil dari rasa kemanusiaan yang timbul untuk sesama. Sedangkan crowdfunding atau urun dana (penggalangan dana) merupakan proses mengumpulkan sejumlah dana yang bertujuan untuk menjalankan suatu proyek atau usaha dan umumnya dilakukan secara daring. Proyek yang dimaksud disini adalah kampanye atau kegiatan bakti sosial itu sendiri.

\section{B. METODE PELAKSANAAN KEGIATAN}

Pelaksanaan program kegiatan Pengabdian Kepada Masyarakat (PKM) ini melalui beberapa tahapan yang telah dilaksanakan, antara lain dapat digambarkan dalam alur berikut:

1. Tahap Persiapan

a. Kegiatan Observasi dan Perizinan

Observasi dilakukan dengan melakukan survey pada lokasi yang akan dijadikan kegiatan Pengabdian Kepada Masyarakat (PKM) dengan terlebih dahulu melakukan pengecekan warga berstatus suspect, orang dalam penanganan (ODP), dan pasien dalam penanganan (PDP) juga dilakukan untuk melihat kondisi perekonomian dari keluarga yang disebutkan, akhirnya berdasarkan data yang telah di temukan di tentukan lokasi Pengabdian Kepada Masyarakat ( PKM ) di Kelurahan Kukusan RT 06 RW 05 Kecamatan Beji Kota Depok Jawa Barat 16425. Dalam tahapan perizinan para dosen berkordinasi dengan pihak terkait, yaitu Lurah Kelurahan Kukusan dan Ketua RT 06 dan Ketua RW 05 agar kegiatan bisa berlangsung sesuai dengan yang di rencanakan.

b. Penyusunan RAB

Rencana Anggaran dan Belanja dipersiapkan dalam hal pembelian belanja bahan seperti: Paket Sembako, cinderamata/plakat, spanduk kegiatan, sertifikat, materi, pembuatan jurnal. 


\section{c. Pengajuan Proposal}

Proposal kegiatan PKM diajukan pada bulan april 2020 dan setelah melalui proses review, disetujui oleh Ketua LPPM Bapak Dr.Ali Madinsyah,S.E.,MM pada awal bulan Mei 2020. Dan langsung di realisasikan kegiatan pada tanggal 19-21 Mei 2020.

2. Tahap Implementasi/ pelaksanaan kegiatan

Pada sesi pemberian sembako pada warga terkena dampak Covid-19, di Keluarahan Kukusan, RT 06 RW 05 Kecamatan Beji, Kota Depok. di awali dengan sambutan, sambutan di sampaikan oleh ibu Mutmainnah,S.E.,M.M selaku ketua pelaksana pada kegitan ini, dalam sambutanya disampaikan untuk tetap optimis dalam situasi Covid-19 dimana keadaan ekonomi yang tidak saja melanda Indonesia akan tetapi juga melanda dunia, sabar dan optimis menghadapi krisis adalah kunci utama dalam menghadapi situasi seperti ini.

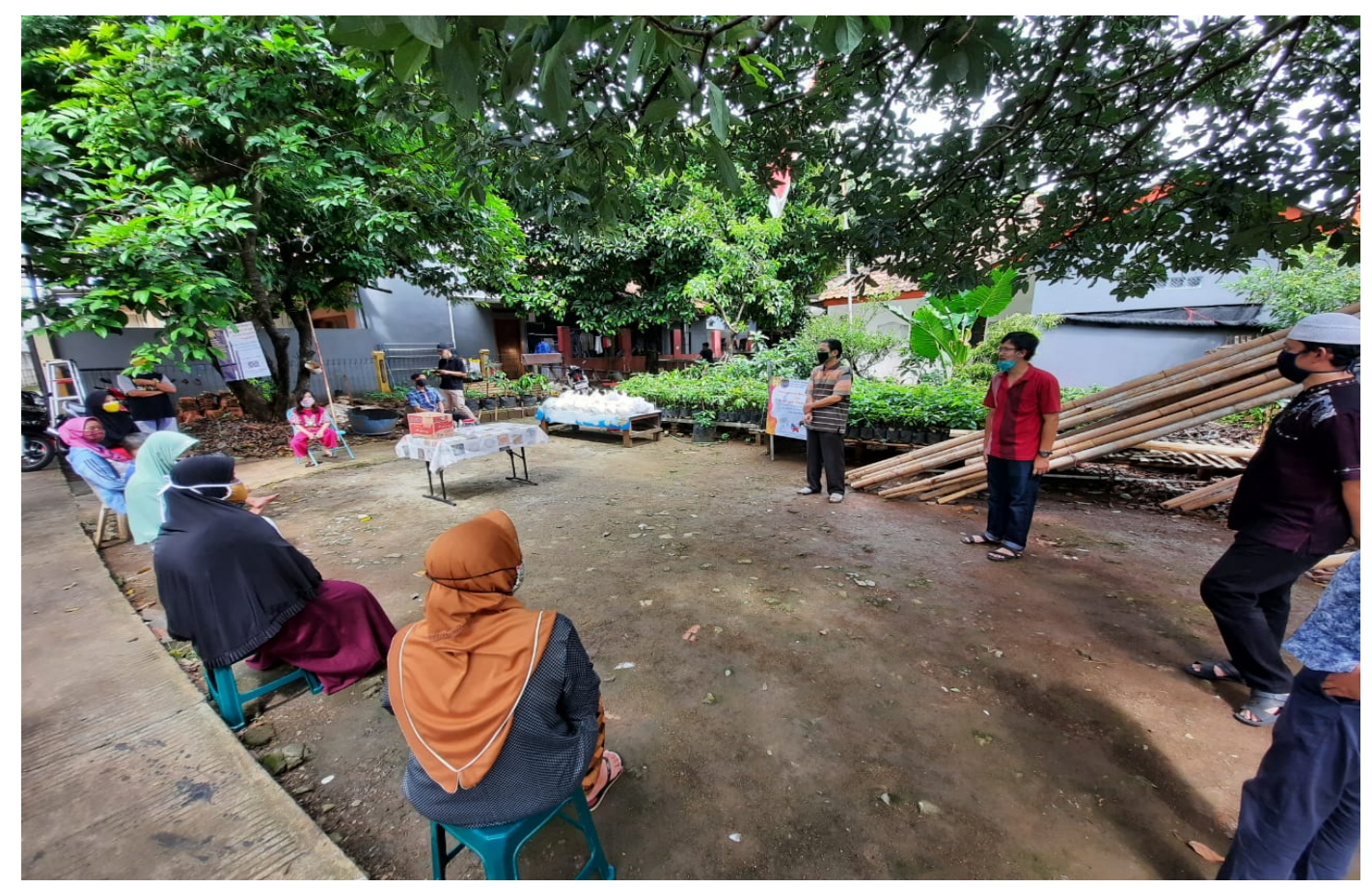

Gambar 1. Pembagian Sembako Terdampak Covid-19

Pada sesi berikutnya setelah sambutan oleh ketua pelaksana, langsung di lakukan pmbagian sembako kepada warga yang terkena dampak Covid-19 karena tim Pengabdian Kepada Masyarakat (PKM) harus mematuhi protokol kesehatan di mana tidak boleh berkumpul lama yang akan memungkinkan terjadinya penularana virus tersebut.

Kegiatan pembagian sembako di tutup dengan doa oleh bapak Ahmad Dimyati, S.Sos.I.,M.Si, yang dalam doanya di sampaikan doa keselamatan akan adanya wabah ini, di berikan kesabaran dalam menjalankan kehidupan di tengah pandemik Covid -19.

\section{HASIL DAN PEMBAHASAN}

Kegiatan Pengabdian Kepada Masyarakat (PKM) ini dilakukan di Kelurahan Kukusan,RT 06 RW 05 Kecamatan Beji, Kota Depok, di hadiri oleh warga yang terkena dampak ekonomi karena pandemic Covid-19 yang berjumlah 75 orang, banyak warga yang kehilangan pekerjaan dan bagi warga yang berdagang juga sepi pembeli sehingga dalam mencukupi kebutuhan makan keluarga juga mengalami kesulitan. 
Dalam kegiatan Pengabdian Kepada masyarakt ( PKM ) ini, di sambut positif baik oleh pihak kelurahan, RT dan RW serta tokoh masyarakat setempat, sehingga kehadiran dosen dengan terjun langsung ke masyarakat melakukan bantuan langsung kepada masyarakat yang membutuhkan serta memberikan motivasi kepada mereka untuk tetap optimis melanjutkan kehidupan di tengah pandemic Covid-19 adalah solusi dari permasalahan yang ada saat ini mereka hadapi.

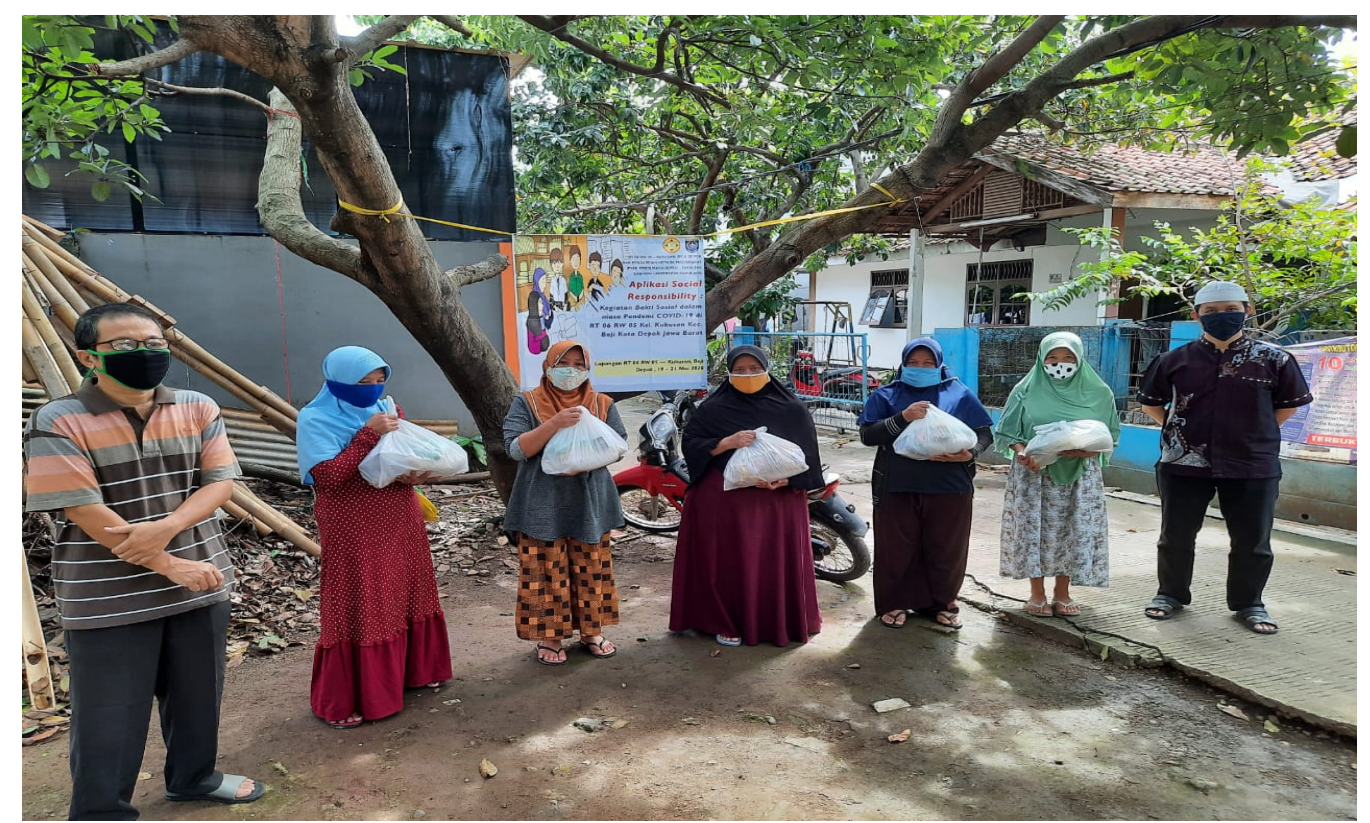

Gambar 2. Foto Perwakilan Penerima Sembako PKM dan Mahasiswa UNPAM

\section{KESIMPULAN DAN SARAN}

\section{Simpulan}

Berdasarkan pelaksanaan kegiatan Pengabdian Kepada Masyarakat yang telah dilaksanakan di Kelurahan Kukusan RT 06 RW 05 Kecamatan Beji Kota Depok Jawa Barat 16425 pada tanggal 18 - 20 Oktober 2019, dapat ditarik kesimpulan bahwa secara umum kegiatan pengabdian kepada masyarakat dapat terlaksana dengan baik. Kegiatan PKM ini mendapat sambutan dan dukungan dari pihak Kelurahan dan Ketua RT dari segi tempat, sarana prasarana dan akomodasi, serta antusiasme para penerima bantuan sembako yaitu warga kurang mampu terdampak Covid-19 di Kelurahan Kukusan RT 06 RW 05 Kecamatan Beji Kota Depok Jawa Barat. Para warga juga mendapatkan arahan dan pengetahuan mengenai pshycal distancing, penggunaan masker dan cara mencuci tangan yang baik dan benar. Diharapkan setelah warga penerima bantuan mengikuti kegiatan PKM tersebut, para warga dapat termotivasi untuk menjalani hidup lebih bersih dan sehat dan dapat menggunakan waktu mereka selama pandemi covid-19 untuk lebih produktif dan kreatif menghasilkan sesuatu yang bernilai jual.

\section{Saran}

Berdasarkan kegiatan yang sudah terlaksana terdapat beberapa saran yang kami sampaikan untuk kemajuan. Saran-saran tersebut adalah baik institusi maupun individu harus tetap meningkatkan kepedulian terhadap sesama baik melalui CSR maupun kegiatan sosial lainnya. Selain itu, bentuk bantuan tidak hanya berupa bantuan secara materiil 
seperti sembako, tetapi juga dapat memberikan pelatihan untuk meningkatkan keterampilan agar dapat bertahan menghadapi pandemic COVID-19.

\section{Ucapan Terima Kasih}

Penulis mengucapkan terima kasih yang tak terhingga kepada ketua Yayasan Sasmita Jaya, LPPM Universitas Pamulang, dan Pihak pengurus majlis taklim Al Auladiyah Pocis, Bakti Jaya Setu-Tangerang Selatan yang telah banyak memberikan dukungan dalam kegiatan PKM ini.

\section{DAFTAR PUSTAKA}

Amerta. 2018. Perkembangan CSR di Indonesia. https://www.amerta.id/2018/04/25/1304/perkembangan-csr-di-indonesia.php. Diakses tanggal 9 Mei 2020 pukul 15.50 WIB.

Dhiani, H.P., Widodo, A.S., Hanum, N., Mutmainnah, M., \& Dimyati, A. 2020. Membangun Motivasi Siswa yang Mampu Memanajemen Waktu dengan Baik. Jurnal Abdi Laksana $1(2)$.

Diniari, E.B. 2018. Sosiologi Kelas 8; Mengenal Kategori Keberagaman Masyarakat Multikultural. $\quad$ https://blog.ruangguru.com/mengenal-kategori-keberagamanmasyarakat-multikultural. Diakses tanggal 9 Mei pukul 14.05 WIB.

Dumilah, R., Sunarto A., Ahyani, Solihin, D., Maulida H. (2020). Pelatihan Pemanfaatan Media Sosial Untuk Promosi Usaha Atau Bisnis Bagi Siswa. DEDIKASI PKM. Vol. 1. No. 1.

Ernawan, E.R. 2014. Tanggung Jawab Sosial Perusahaan (Corporate Social Responsibility). Program Studi Manajemen Universitas Pasundan. Jurnal Manajemen dan Bisnis Performa XI (2).

Isman, A.M. 2017. Tanggung Jawab Sosial Dalam Manajerial. https://afifmaulanaisman.wordpress.com/2017/08/23/tanggung-jawab-sosial-dalammanajerial/. Diakses tanggal 9 Mei 2020 pukul 15.00 WIB.

Kompas.com. 2020. Update : 6 Kabar Baik Soal Penanganan Virus Corona. https://www.kompas.com/tren/read/2020/04/01/190000965/update-6-kabar-baik-soalpenanganan-virus-corona-di-indonesia?page=3. Diakses tanggal 9 Mei 2020 pukul 16.25 WIB.

Mutmainnah, M., Dhiani, H. P. (2020). Kisah Nabi Sebagai Peningkatan Motivasi Dalam Kegiatan Santriwan/Wati Ditaman Pendidikan Alqur'an Miftahul Huda. Jurnal ABDIMAS, 1(1).

Solihin, D. (2020), Mulai Usaha di Masa Pandemi? Ini 'Analisis SWOT' Strateginya. rakyatmerdekanews.com. 